\begin{tabular}{|c|c|c|}
\hline Q) & $\begin{array}{c}\text { Türkiye Tarımsal Araştırmalar Dergisi } \\
\text { dergipark.org.tr/tutad }\end{array}$ & $\begin{array}{l}\text { Turk J Agric Res } \\
\text { 2020, 7(1): 105-110 } \\
\text { @ TÜTAD } \\
\text { ISSN: 2148-2306 }\end{array}$ \\
\hline $\begin{array}{l}\text { UNNIVERSiTESI } \\
\text { Bilimin Nüumanda }\end{array}$ & Research Article & $\begin{array}{l}\text { e-ISSN: } 2528-858 \mathrm{X} \\
\text { doi: } 10.19159 / \text { tutad.676527 }\end{array}$ \\
\hline
\end{tabular}

\title{
Comparison of Leadership Styles of University Students in Terms of Their Demographic Characteristics
}

\author{
Osman KILIÇ*, İsmet BOZ, Uğur BAŞER \\ Ondokuz Mayls University, Faculty of Agriculture, Department of Agricultural Economics, Samsun, TURKEY
}

\begin{tabular}{l}
\hline \multicolumn{1}{c}{ Received: $17.01 .2020 \quad$ Accepted: 27.02 .2020} \\
\hline ORCID ID (by author order) \\
(D)orcid.org/0000-0002-0129-4034 (D) orcid.org/0000-0001-7316-9323 (1D) orcid.org/0000-0003-4961-2764 \\
${ }^{*}$ Corresponding Author: okilic@omu.edu.tr
\end{tabular}

\begin{abstract}
The primary purpose of this study was to determine the Kurt Lewin's leadership styles of college students and also to determine whether their leadership styles differ with their demographic characteristics or not. The participants were 384 students sampled from the total student population of Ondokuz Mayis University in Turkey, based on Cochran's sample size determination formula for categorical data collection instruments. Overall, $49.2 \%$ of the respondents were democratic leaders $34.9 \%$ were autocratic, and $15.9 \%$ were laissez-faire style leaders. The Chi-square test, conducted on the variables of leadership style and demographic characteristics of students, revealed significant effects of gender and parents' place of residence but was independent of other factors. Female respondents and respondents coming mostly from rural and suburban areas tended to be more democratic leaders in comparison with male respondents and respondents coming from more densely populated or metropolitan areas. The study suggests that similar researches should be conducted to determine the influence of leadership style on the performance of workers employed in different businesses in Turkey.
\end{abstract}

Keywords: Leadership, leader, leadership styles, higher education, student

\section{Introduction}

Leadership is a widely-used concept in every part of human life, including the developing world. It has become a key element of success for many organizations operating in the public and private sector, as well as in Non-Governmental Organizations (NGOs) and organizations with workers who volunteer. Although there is a belief that leaders are born and not made, many public and private institutions invest in their human resources to develop leadership skills. These institutions include ministries, directorates, provincial and district governorships, military and other security organizations, as well as private companies in construction, mining, business and marketing, and institutes of education and volunteer organizations.

One of the oldest definitions of leadership states that it is the activity of influencing people to cooperate toward some goal, which they come to find desirable (Tead, 1935). As cited in Sykes (2012), Tead (1935) stated that a leader is one who knows with greater than average strength of intuition what he wants to get done and where he wants to go. 'The world stands aside to let pass the man who knows whether he is going'. This means that he possesses clarity and precision as to the objectives, purposes, or aims that he desires for himself and his group and that he holds these deeply enough and permanently enough to see them well on the way to being realized. Purposefulness, to be effective, requires that the aims are: (1) definite; (2) readily communicable to others; (3) potentially attractive to others; and (4) vigorously, persistently, and enthusiastically sustained by the leader (Sykes, 2012). Although the above definition of leadership refers to men, there have been many women leaders such as Indira Gandhi, Joan of Arc, Benazir Bhutto, Margaret Thatcher, and Angela Merkel, and the characteristics of leadership apply to them.

Leadership is further defined as behavior that influences, guides or controls a group (Beebe and Masterson, 1994) and the process of influencing the activities of a group of people by a leader in efforts 
towards the achievement of goals (Nworgu, 1991). A leader is a creative person who leads, teaches, and illuminates people as well as senses and organizes their wishes and needs (Erçetin, 1998; Tosun, 1992).

An integrative definition of a leader is a person who selects, equips, trains and influences one or more followers who have diverse gifts, abilities, and skills and focuses the followers on the organization's mission and objectives, causing the followers to willingly and enthusiastically expend spiritual, emotional and physical energy in a concerted, coordinated effort to achieve the organizational mission and objectives (Winston and Patterson, 2006). To be a leader, one must be inspired and followed by others. Some leaders may have millions of followers, while others have only a few. The number of followers does not prevent one's position as a leader. According to leadership theories, there is no leader without at least one follower, meaning that having only one follower can make an individual a leader (Kellerman, 2007).

Leaders are rarely satisfied with the present situation of their organizations, and they attempt to make significant changes in these organizations. These changes benefit all individuals and the organization as a whole. To handle this mission, leaders must have many abilities and skills. The most important are coaching, rewarding, communicating, motivating, involving and supporting others, and promoting teamwork and collaboration (Kotter, 1996; Nadler, 1997; Gilley, 2005; Gilley et al., 2008). Beside professional organizations, these abilities can also be applied to other social or home situations where people must lead.

There are different ways of leading individuals to achieve goals. These are called leadership styles, and social scientists classify them via a variety of means. Leadership styles are relatively stable patterns of behavior manifested by leaders (Eagly and Johannesen-Schmidt, 2001; Eagly et al., 2003). Three of the most common leadership styles are democratic, autocratic and laissez-faire, as described in the Kurt Lewin Styles of Leadership (Lewin et al., 1939). These were used in a quiz (Prawl et al., 1984) to determine the leadership styles of individuals. This quiz is now the main instrument used for the data collection on research into leadership.

The autocratic leader thinks that he/she is more talented and skillful than others and her/his ideas must be put in the process without being criticized. $\mathrm{He} / \mathrm{she}$ wants to control all stages of decisionmaking and rarely accepts any input from her/his followers. Autocratic leaders make decisions themselves. They do not consult their followers or involve them in the decision-making process. Having made a decision, they impose it and expect obedience.

Researchers found that decision-making was less creative under authoritarian leadership. Levin et al. (1939) also concluded that it is harder to move from an authoritarian style to a democratic style than vice versa. Abuse of this method is usually viewed as controlling, bossy and dictatorial.

Democratic leaders take an active role in the decision-making process, but they also involve others. Despite the term "democratic", they don't necessarily put decisions to the vote. Of course, they still carry the responsibility for seeing that decisions achieve the desired outcomes.

Laissez-faire leaders have very little involvement in decision-making themselves and leave this to their followers. This might be okay when the followers are capable and motivated, but it can create problems. The primary purpose of this study was to explore the leadership styles of university students, based on the Kurt Lewin Styles of Leadership, and to determine if demographic characteristics and career objectives differ significantly among the students belonging to each of the three leadership styles.

\section{Materials and Methods}

The main material for this study was information acquired by administering a leadership style quiz (Prawl et al., 1984), followed by a questionnaire for personal information and career-seeking options. The population was students of Ondokuz Mayis University in Samsun, Turkey. The majority of the data were collected on categorical scales and thus Cochran's sample size determination Equation 1 for categorical data was used to determine the accurate sample size. The Cochran Equation, as presented by Barlett et al. (2001):

$$
n=\frac{(t)^{2}(p)(q)}{(d)^{2}}, n=\frac{(1.96)^{2}(0.5)(0.5)}{(0.05)^{2}}=384
$$

Where $t$ is the value for the selected alpha level of 0.025 in each tail (1.96), (p) and (q) represent the estimate of variance ( 0.5 each), and $\mathrm{d}$ is the acceptable margin of error for the proportion being estimated (0.05). Since this sample size did not exceed $5 \%$ of the population, the small population correction formula (Cochran, 1977) was not used.

The data collection instruments of this study consisted of two sections-the first one was adapted from the quiz of leadership styles of Prawl et al. (1984) and aimed to determine the leadership styles of the respondents with 18 questions with 'yes/no' 
answers. The quiz included six questions for each of the three leadership styles: autocratic, democratic, and laissez-faire. For example, an autocratic question was "Do you enjoy running the show?"; a democratic question was "Generally, do you think it's worth the time and effort to explain the reasons for a decision or policy before putting it into effect?"; and finally, a laissez-faire question was "Do you find that in giving out assignments, you tend to state the goal and leave the methods to your subordinates?" All of the 18 questions were placed in the questionnaire in mixed order so that the respondent did not know which question belonged to which leadership style. The leadership styles of the respondents were determined by adding up their "yes" responses in each category. The category which includes the highest number of "yes" answers represents the leadership style of the respondent.

The second part of the questionnaire included questions on personal information such as gender, age, level of education, major study area, grade point average, monthly expenditure, parents place of residence, occupation of father, occupation of mother, career goals, and whether or not the respondent agreed with her/his leadership style.

Data were collected by survey in 2018, and it took approximately 15 minutes to complete one questionnaire. Descriptive statistics were used to determine the leadership styles and demographic characteristics of the students. The Chi-squared $\left(\chi^{2}\right)$ test of independence was used to determine if significant associations $(\mathrm{p}<0.05)$ existed between leadership styles and demographic characteristics of the students.

\section{Results}

The demographic characteristics of the respondents are presented in Table 1; 56.3\% of the respondents were male and $43.8 \%$ were female. More than half $(53.4 \%)$ were $21-24$ years old, $41.1 \%$ were 20 or less, and $5.5 \%$ were 25 or older. In terms of the major area of study, $41.7 \%$ were pursuing a career in social or educational sciences, while $38.8 \%$ were studying science or engineering, and $19.5 \%$ were in the health sciences such as medical school, dentistry, veterinary school, nursing, and healthcare education. More than half of the respondents' $(57.8 \%)$ monthly expenditure was between 501 and 1.000 Turkish Lira (TL), and the residences of almost half $(45.3 \%)$ of their families were in metropolitan areas. The fathers had a large variety of occupations, including government officers, workers, farmers or business owners. Most (68.9\%) of the mothers were occupied in housework (Table $1)$.
Table 1. Demographic characteristics of the respondents

\begin{tabular}{|c|c|c|}
\hline Demographic characteristics & Count & $\%$ \\
\hline \multicolumn{3}{|l|}{ Gender } \\
\hline Male & 216 & 56.3 \\
\hline Female & 168 & 43.8 \\
\hline Total & 384 & 100.0 \\
\hline \multicolumn{3}{|l|}{ Age } \\
\hline$\leq 20$ & 158 & 41.1 \\
\hline $21-24$ & 205 & 53.4 \\
\hline $25 \leq$ & 21 & 5.5 \\
\hline Total & 384 & 100.0 \\
\hline \multicolumn{3}{|l|}{ Major area of study } \\
\hline Science and engineering & 149 & 38.8 \\
\hline Social and educational sciences & 160 & 41.7 \\
\hline Health sciences & 75 & 19.5 \\
\hline Total & 384 & 100.0 \\
\hline \multicolumn{3}{|l|}{ Monthly expenditures (TL) } \\
\hline$\leq 500$ & 108 & 28.1 \\
\hline $501-1000$ & 222 & 57.8 \\
\hline $1001 \leq$ & 54 & 14.1 \\
\hline Total & 384 & 100.0 \\
\hline \multicolumn{3}{|l|}{ Residential area of the family } \\
\hline Metropolitan & 174 & 45.3 \\
\hline City & 80 & 20.8 \\
\hline District & 99 & 25.8 \\
\hline Village & 31 & 8.1 \\
\hline Total & 384 & 100.0 \\
\hline \multicolumn{3}{|l|}{ Occupation of father } \\
\hline Government officer & 95 & 24.7 \\
\hline Teacher, engineer, doctor, judge & 40 & 10.4 \\
\hline Worker, farmer & 92 & 24.0 \\
\hline Own business & 100 & 26.0 \\
\hline Retired & 57 & 14.8 \\
\hline Total & 384 & 100.0 \\
\hline \multicolumn{3}{|l|}{ Occupation of mother } \\
\hline Government officer & 28 & 7.3 \\
\hline Teacher, engineer, doctor, judge & 33 & 8.6 \\
\hline Worker, farmer & 19 & 4.9 \\
\hline Own business & 25 & 6.5 \\
\hline Home duties & 268 & 68.9 \\
\hline Retired & 11 & 2.9 \\
\hline Total & 384 & 100.0 \\
\hline
\end{tabular}

Table 2 shows the leadership styles, academic success, and career preferences of the students. Almost half of the students were classified as having a democratic leadership style, about onethird were autocratic, and the smallest proportion $(15.9 \%)$ had a laissez-faire style. One-third of the respondents wanted to pursue a career as a government employee after graduation, while slightly more than one-fourth wanted to establish their own business. One-fifth wanted to become academics, and slightly less than one-fifth wanted to work in the private sector. In terms of academic success, almost half of the respondents had a grade point average (GPA) of 2.51-3.00, slightly more than one-fourth had a GPA of 2.50 or below, and only $5.7 \%$ were higher than 3.50 . Almost half of the respondents $(47.1 \%)$ agreed with their leadership 
style attributed to them by the questionnaire while $22.4 \%$ strongly agreed, $23.4 \%$ were neutral, and only $7 \%$ disagreed (Table 2 ).

Table 2. Leadership styles, academic success, and career goals

\begin{tabular}{lrr}
\hline Leadership style & Count & $\%$ \\
\hline Autocratic & 134 & 34.9 \\
Democratic & 189 & 49.2 \\
Laissez-faire & 61 & 15.9 \\
Total & 383 & 100.0 \\
\hline Grade point average & & \\
2.50 or less & 102 & 26.6 \\
$2.51-3.00$ & 190 & 49.5 \\
$3.01-3.50$ & 70 & 18.2 \\
$3.51-4.00$ & 22 & 5.7 \\
Total & 384 & 100.0 \\
\hline Career decision & & \\
Academic & 77 & 20.1 \\
Public servant & 128 & 33.3 \\
Work for private sector & 69 & 18.0 \\
Own business & 110 & 28.6 \\
Total & 384 & 100.0 \\
\hline Agreed with leadership style & & \\
Strongly agree & 86 & 22.4 \\
Agree & 181 & 47.1 \\
Neutral & 90 & 23.4 \\
Disagree & 27 & 7.0 \\
Total & 384 & 100.0 \\
\hline
\end{tabular}

Table 3 shows Chi-square analyses between leadership styles and demographic variables, academic success, career goals, and whether or not respondents agreed or disagreed with their identified leadership styles. Variables were ranked according to their significance levels. Of ten chisquare tests performed, two variables were statistically significant at an alpha of $0.05(\mathrm{p}<0.05)$. These included the parents' place of residence and gender. Overall, results of the chi-square tests of independence showed that leadership style was significantly associated with the variables parents' place of residence and gender, but independent of occupation of mother, perception of leadership style ascribed, career goals, major study area, grade point average, occupation of father, and monthly expenditure (Table 3).

Cross-tabulation of two significant variables (parents' place of residence and gender) is presented in Table 4. In terms of parents' place of residence, $53.0 \%$ of autocratic leaders' parents live in metropolitan areas, while $21.6 \%$ in cities, $19.4 \%$ in districts, and $6.0 \%$ in villages; these were classified by law, based on their total population. Of the democratic leaders, $39.7 \%$ came from metropolitan areas, $22.2 \%$ from cities, $31.2 \%$ from districts, and $6.9 \%$ from villages. The same

Table 3. Chi-square analyses of leadership styles and demographic variables, academic success, career goals, and perception of leadership style described

\begin{tabular}{lccc}
\hline Variable & Degrees of freedom & $\chi^{2}$ & $\mathrm{P}^{*}$ \\
\hline Parents' place of residence & 6 & 15.136 & 0.019 \\
Gender & 2 & 7.198 & 0.027 \\
Occupation of mother & 8 & 14.601 & 0.067 \\
Age & 4 & 6.719 & 0.151 \\
Perception of leadership style described & 6 & 6.915 & 0.329 \\
Career goals & 6 & 6.778 & 0.341 \\
Major study area & 4 & 2.823 & 0.588 \\
Grade point average & 6 & 4.020 & 0.674 \\
Occupation of father & 8 & 5.178 & 0.738 \\
Monthly expenditures & 4 & 1.912 & 0.752 \\
\hline
\end{tabular}

*: Significance level

Table 4. Cross tabulation of significant variables

\begin{tabular}{|c|c|c|c|c|c|c|}
\hline \multirow[t]{2}{*}{ Demographic characteristics } & \multicolumn{2}{|c|}{ Autocratic } & \multicolumn{2}{|c|}{ Democratic } & \multicolumn{2}{|c|}{ Laissez-faire } \\
\hline & Count & $\%$ & Count & $\%$ & Count & $\%$ \\
\hline \multicolumn{7}{|l|}{ Residential area of origin } \\
\hline Metropolitan & 71 & 53.0 & 75 & 39.7 & 23 & 37.6 \\
\hline City & 29 & 21.6 & 42 & 22.2 & 14 & 23.0 \\
\hline District & 26 & 19.4 & 59 & 31.2 & 14 & 23.0 \\
\hline Village & 8 & 6.0 & 13 & 6.9 & 10 & 16.4 \\
\hline Total & 134 & 100.0 & 189 & 100.0 & 61 & 100.0 \\
\hline \multicolumn{7}{|l|}{$X^{2}=15.136, p=0.019$} \\
\hline \multicolumn{7}{|l|}{ Gender } \\
\hline Male & 81 & 60.4 & 94 & 49.7 & 41 & 67.2 \\
\hline Female & 53 & 39.6 & 95 & 50.3 & 20 & 32.8 \\
\hline Total & 134 & 100.0 & 189 & 100.0 & 61 & 100.0 \\
\hline
\end{tabular}


breakdown of figures for laissez-faire leaders was $37.6 \%, 23.0 \%, 23.0 \%$, and $16.4 \%$, respectively. Application of the Chi-square test of independence to the variables, leadership style and parents' place of residence, showed a statistically significant association. This association showed that the respondents from more densely populated residential areas were more autocratic. Conversely, those from less populated and more rural areas were more likely to be democratic or laissez-faire leaders. In terms of the gender variable, $60.5 \%$ of autocratic leaders were male and $39.6 \%$ were female. The rates for females and males were $50.3 \%$ and $49.5 \%$ for democratic leadership, respectively, and $32.8 \%$ and $72.7 \%$ for laissez-faire leaders, respectively. The Chi-square test of independence conducted on gender and leadership style showed a statistically significant association between these two variables $(p<0.05)$. Overall, males tended to have more extreme leadership styles (autocratic and laissez-faire), while females were more democratic (Table 4).

\section{Discussion and Conclusions}

This study identified the leadership styles of university students and whether the identified leadership styles are associated with their sociodemographic characteristics. The sociodemographic profile of college students could represent the average profile of a college student attending state universities in the Anatolian cities of Turkey. This is because students take the national university entrance exam and come to Samsun and Ondokuz Mayis University from many different provinces of Turkey. An average student would be a 20-25 years old female or male coming from a medium-income family living in an urban or suburban area, whose parents hold an elementary school certificate, with the father engaged in work outside the home, and mother most likely doing housework.

The discussion of the results of this study is focused on significant findings related to two variables, namely the parents' place of residence and gender of the respondents. Those who came from the more densely settled residential areas such as metropolitan areas and large cities were attributed more autocratic leadership style than those who came from rural areas, namely districts and villages. Although no earlier studies directly relevant to these variables were found, factors such as housing, education, unemployment, environmental problems, and inequalities in the rapid urbanization process in Turkey have affected individuals in different ways, some of which are related to political problems and mental health (Turan and Beşirli, 2008), attitudes and behavior
(Kartal, 1978), crime (Karasu, 2008; Gökulu, 2010) and sense of identity (Ulu and Karakoç, 2004; Tatlidil, 2009). Rapid and relatively uncoordinated urbanization may be creating more autocratic leaders; difficulties and dealing with more rules in every part of the work and social environment in metropolitan areas may influence people to act in a more autocratic way.

The second significant variable was gender. The percentage of male and female democratic leaders was almost equal but males tended to be more autocratic or laissez-faire leaders than females; for males, the rates of these two leadership styles were substantially higher than the rates for females. A review of the related literature focused on the relationship between gender and leadership styles revealed similar results. According to the metaanalyses of Eagly and Johnson (1990), Eagly et al. (1992a) and Eagly and Carli (2003), women exhibited relatively more interpersonal and democratic styles than men, and men showed relatively more task-oriented and autocratic styles than women. A study involving school principals produced the largest gender difference, with female principals adopting a more democratic or participative style and a less autocratic or directive style than male principals (Eagly et al., 1992b).

In the present study, although no significant association was found between leadership style and academic success, as measured with the GPA of the student respondents, future research could be directed to finding if leadership styles influence the performance of employees in different businesses in Turkey.

\section{References}

Barlett, J.E., Kotrlik, J.W., Higgins, C.C., 2001. Organizational research: Determining appropriate sample size in survey research. Information Technology, Learning, and Performance Journal, 19(1): 43-50.

Beebe, S.A., Masterson, J.T., 1994. Communicating in small groups: Principles and practices. Fourth Edition, Harper Collins College Publishers, New York.

Cochran, W.G., 1977. Sampling Techniques. Third Edition, John Wiley \& Sons, New York.

Eagly, A.H., Carli, L.L., 2003. The female leadership advantage: An evaluation of the evidence. The Leadership Quarterly, 14(6): 807-834.

Eagly, A.H., Johannesen-Schmidt, M.C., 2001. The leadership styles of women and men. Journal of Social Issues, 57(4): 781-797.

Eagly, A.H., Johannesen-Schmidt, M.C., Van Engen, M.L., 2003. Transformational, transactional, and laissez-faire leadership styles: A meta-analysis 
comparing women and men. Psychological Bulletin, 129(4): 569-591.

Eagly, A.H., Johnson, B., 1990. Gender and leadership style: A meta-analysis. Psychological Bulletin, 108(2): 233-256.

Eagly, A.H., Karau, S.J., Johnson, B.T., 1992b. Gender and leadership style among school principals: A meta-analysis. Educational Administration Quarterly, 28(1): 76-102.

Eagly, A.H., Makhijani, M.G., Klonsky, B.G., 1992a. Gender and the evaluation of leaders: A metaanalysis. Psychological Bulletin, 111(1): 3-22.

Erçetin, S., 1998. Lider Sarmalında Vizyon. Önder Matbaacılık Ltd. Şti., Ankara, Türkiye.

Gilley, A., 2005. The Manager as Change Leader. Westport, CT: Praeger.

Gilley, A., Dixon, P., Gilley, J.W., 2008. Characteristics of leadership effectiveness: Implementing change and driving innovation in organizations. Human Resource Development Quarterly, 19(2): 153-169.

Gökulu, G., 2010. City Safety and relationship between urbanization and crime. Atatürk University Journal of Economics and Administrative Sciences, 24(1): 209226. (in Turkish).

Karasu, M.A., 2008. The effect of Turkey's urbanization dynamics on crime. Ankara Üniversitesi Hukuk Fakültesi Dergisi, 57(4): 255-281. (in Turkish).

Kartal, S.K., 1978. Kentleşme ve İnsan: Kentleşme Sürecinde İnsan Tutum ve Davranışlarında Meydana Gelen Değişmeler: Çankırı Köylerinden Ankara'ya Göç Edenler Üzerinde Bir Araştırma. Türkiye ve Orta Doğu İdaresi Enstitüsü Yayınları, No. 175.

Kellerman, B., 2007. What every leader needs to know about followers. Harvard Business Review, 85(12): 84-91.
Kotter, J.P., 1996. Leading Change. Harvard Business School Press, Boston.

Lewin, K., Lippitt, R. White, R.K., 1939. Patterns of aggressive behavior in experimentally created "social climates". Journal of Social Psychology, 10: 271299.

Nadler, D.A., 1997. Champions of Change: How Ceos and Their Companies Are Mastering The Skills of Radical Change. San Francisco: Jossey-Bass.

Nworgu, B.G., 1991. Educational Research: Basic Issues and Methodology. Ibadan, Wisdom Publishers.

Prawl, W., Medlin, R., Gross, J., 1984. Adult and Continuing Education Through The Cooperative Extension Service. Extension Division, University of Missouri, Columbia.

Sykes, W., 2012. Visions of Hope: Leadership. Open Writings, (http://www.openwriting.com/archives/visions of $\mathrm{h}$ ope/), (Accessed: 29.12.2018).

Tatl1dil, E., 2009. Identity of cities and citizens; the case of Izmir. Ege Akademic Review, 9(1): 319-336. (in Turkish).

Tead, O., 1935. The Art of Leadership. McGraw-Hill Book Company.

Tosun, K., 1992. İşletme Yönetimi: Genel Esaslar. Savaş Yayınları, Ankara.

Turan, M.T., Beşirli, A., 2008. Impacts of urbanization process on mental health. Anatolian Journal of Psychiatry, 9(4): 238-243. (in Turkish).

Ulu, A., Karakoç, İ., 2004. The influence of urbanization on city identity. Journal of Planning, 29(3): 59-66. (in Turkish).

Winston, B.E., Patterson, K., 2006. An integrative definition of leadership. International Journal of Leadership Studies, 1(2): 6-66. 